\title{
CHINA AND ITS CONTRIBUTION IN ADDRESSING PEACE AND SECURITY THREATS IN HORN OF AFRICA
}

\author{
Assefa Leake Gebru \\ PhD Candidate at ECNU, Department of Politics, IGPP
}

\begin{abstract}
The Horn of Africa is a term given to the geographic map in the North East part of the African continent. In its wider spatial conception, geopolitical significance, communalities of challenges of peace and security, the nature of state politics and relations, the fluctuating nature of conflict and cooperation, as well as convergence and divergences of interests, the region encompasses eight countries. The region connects Africa with Europe, Asia and the wider Middle east region as it protrudes into the Gulf of Aden, the Indian Ocean and the Red Sea, which is the longest trade route connecting the Suez Canal in the north via Bab el Mandeb to the Indian Ocean. Despite its geopolitical significance, the region remains one of the most unstable, underdeveloped and volatile security in Africa. These multiple challenges and interlinkages affect not only the region but also the international community in variety if its forms, piracy and terrorism are few cases to mention. This calls the involvement of responsible big powers, either as they are responsible to play their part in the maintenance of international peace and security or due to their geopolitical and commercial interest or a merger of all. Currently various powers are engaged in the promotion of peace and security in the region, of which China is one. In lieu of this, then, this paper has examined the major tasks that China is engaged in the promotion of peace and security in the region, presided by theoretical frameworks pertaining to peace and security as well as big power responsibility.
\end{abstract}

Keywords: Peace and Security, Big Power Responsibility, Peacekeeping, Pirates

\section{INTRODUCTION}

There is no agreement among academics on the exact definition of the Horn of Africa region. Different scholars have suggested what the Horn includes and excludes based on different considerations: some wider and some narrower in scope and implication based on divergent geopolitical considerations. The following are some instances of the delineation of the Horn of Africa made by academics based on major parameters. For scholars of US foreign policy in the Horn like Peter Woodward (Woodward, 2002.), the term 'Horn of Africa' is not an indigenous one; rather than a name that springs from a glance at a map rather than any 
International Journal of Arts and Humanities

ISSN: 2581-3102

Volume: 04, Issue: 03 "March 2020"

perception of inhabitants of that area of north-east Africa. Indeed, among this category of scholars, there is no agreement on exactly what it is; in addition to states conventionally accepted as part of the Horn region (like Ethiopia, Somalia and Djibouti), they consider the concept of the Horn as an extension and outgrowth of concerns around the nature of inter-state relations; in particular 'from an early concern about Somalia's relations with Ethiopia, to take in all of the latter's problems, and then increasingly to include Sudan as well. Another consideration is history that defined the convergence and divergence of states and peoples of the region.

Though in Africa, the Horn is not always of Africa: its history is as much linked to Arabia as to Africa, including the influence of Islam. Thus the broad context for Middle East policy, including the Arab-Israeli dispute, may be as relevant for understanding US policy towards the region. Thus, 'the Horn' is defined as comprising Ethiopia, Djibouti, Somalia (including what is now known as Somaliland), Sudan and Eritrea since its independence from Ethiopia in1993 (ibid). Others defined the Horn of Africa (HoA) sub region in terms of shared opportunities and challenges as comprising Djibouti, Eritrea, Ethiopia, Somalia and Sudan, but other analysts have included Kenya in the sub region, while some others have excluded Sudan from it (Lyons, 1992; Bereket, 1980). One also sometimes encounters the term "Greater HoA", defined as comprising the Horn itself as well as Kenya, Uganda and Tanzania. Inbetween the two is the delimitation of the sub regional organization IGAD (Intergovernmental Authority on Development), to which Kenya and Uganda, but not Tanzania, belong as members (Juma, 2003;BJØRN, 2007). In this sense therefore, the Horn of Africa is equivalent to the Greater Horn of Africa minus Tanzania.

Scholars concerned with geostrategic reasons add recent issues, like terrorism, integrating the Horn with the Greater Horn. Accordingly, in an era of terror, Yemen belongs naturally to this greater Horn of Africa region, adding another 20 million people, virtually all Muslims. Although not necessarily cohesive physically, despite the unifying Rift Valley theme (from the Sudan and Djibouti south through Ethiopia and into Kenya), in the global battles for freedom and democracy and against terrorism these seven nation-states (Djibouti, Eritrea, Ethiopia, Kenya, Somalia, the Sudan, and Yemen) astride the Red Sea, the Gulf of Aden, and the Indian Ocean share a common enemy. They also roughly share a paucity of resources and unfulfilled desires for rapid economic advancement (Robert, 2005).

Given this as might so be imperative in the understanding of states of the region in the Horn of Africa, many scholars prefer to define the Horn of Africa using a very conventionally accepted key states as comprising of Ethiopia, Eritrea, Somalia and Djibouti, although it embraces geopolitically the adjoining states of Uganda , Sudan, south Sudan, and Kenya (Danfulani,1999; Farer, 1979). 
International Journal of Arts and Humanities

ISSN: 2581-3102

Volume: 04, Issue: 03 "March 2020"

This is obviously equivalent or equals to the IGAD region, where many scholars define the region in terms of membership to the sub regional organization IGAD to which the African Union and the United Nations gave their political support and legal recognition. Hence, conceptualizing the Horn of Africa throughout the whole paper need be understood in terms of a region that comprises above mentioned eight states, which are all members of the IGAD regional framework for peace and security.

The region is known for its volatile security landscape and continuous political instability, in which conflicts of all sorts' amess the region for a long period of its history. Dominant number of states of the region are fragile, weak and incapable of maintaining effective control of their respective boundaries. At worst internal disagreements and conflicts seen to have a grave consequence in initiating inter-state conflicts, same is also true for inter-state conflicts to have an impact in both initiating or aggravating internal divisions and conflicts. Underdevelopment and poverty that define the scope of regional economic debacle seemed aggravated due to poor governance and resource diversion from peace time use into military preparedness thereby to cover costs of military armaments and equipment. All these challenges put states and peoples of the region in the same boat. Hence, addressing security challenges and promoting peace in the region is utmost agenda of the region of Horn of Africa.

Owing to this fact, various major powers are contributing their fair share. For a very long period of time, the US is there playing the role of peacemaking efforts like in the case of Somalia, conflict resolution in the North- South Sudanese civil war and trying to deter the proliferation of terrorism in the Red Sea and Somalian coastal areas. And very recently some big powers are playing their part in the promotion of peace and security in the region either in collaboration with states of the region or via multilateral organization of Universal, Regional and Sub-regional in nature. Inter-allia, the coming of China to the regional scenario is a case in point. Driven by its geopolitical, politico-economic interests and /or to discharge its major power responsibility China is engaged in the security matters of the region. Notwithstanding its economic interest in the region, it is playing a pivotal role in the addressing conflicts in the region and in post conflict peace building endeavors.

China as new global actor is playing a praiseworthy task in the promotion of peace and security in the region. China's role in the mediation efforts of the ongoing Civil war in South Sudan and Sudan (the Darfur issue), and its fight against pirates in the Coastal areas of Somali are cases in point. Besides, the One Belt One Road initiative that is assumed to connect Africa via this region has further forced China to reinvigorate its efforts in the same task, which demands academic and research engagement. In light of this, therefore, the paper will look in to the empirical evidences where China is engaged in the promotion of peace and Security in the region of the Horn of Africa. In doing this, the paper will first look into the Geopolitical settings of the region 
International Journal of Arts and Humanities

ISSN: 2581-3102

Volume: 04, Issue: 03 "March 2020"

and then it will provide some theoretical frameworks pertaining to the major power responsibility and some basic concepts in the area of conflict, conflict resolution, peace and security promotion strategies to be followed by the practical engagement of China in the area of concern.

\section{GEOPOLITICAL SETTINGS AND SIGNIFICANCE OF THE HORN OF AFRICA REGION}

The Horn is located in the most paradoxical part of the world filled with contradictory and complex overlap of multiple features. Located at the cross roads to the strategic oil field in the Middle East, the vast market of Asia, the pass way to Europe-the street of Bab el mandeb, proximity to the Gulf of Aden, the Persian gulf and close social, historical and cultural attachment to the home of the three Abrhamic religions makes the Horn ample geostrategic significance. Historically, the region has been center of attraction for big powers from the time of ancient empires, through the US vs USSR rivalry of the Cold War to the Post-Cold War multipolar world of our era; the fact of new emergent powers like China and India coming to the region is reiteration of the continued politico-economic and military strategic significance of the Horn for whosoever power that be. Despite the brief declining significance in the early 1990s with the end of the Cold War, the interest of old and new big powers have reinvigorated with the rise of Political Islam and the threat of global terror and the imperative for the global war against it.

States and Peoples of the region are inter connected by interdependent multiple needs and strategic resources like the Nile that kept them linked to the states and peoples of the Great lakes region and Egypt; a view from Ethiopia exhibits same interconnectedness and convergence of states through rivers and infrastructures : except with Djibouti and Somali land via the life line to the cost, Mereb with Eritrea, Turkana with Kenya, Tekeze, Baro and Abay with Sudan and South Sudan, Wabishebele or Jebel with Somalia. The shared identity and social infrastructures along the state borders and border lands are additional potentials for cooperative engagement against hunger, war and the multiple vagaries of overall insecurity that happened to define the regional scenario.

Unfortunately, these multifaceted potentials and strategic significances have continued to be source of mainly woe than peace and development for the states and peoples of the region. The grim picture notwithstanding, both the challenges and opportunities are blessing in disguise for constructive transformation of the region into sustainable peace and prosperity, however. Having this general picture in mind, now let's examine the geopolitical significance of the region taking major reference points in the 'Greater Horn' and the proximate neighborhood of the Middle East that more or less provide a clear image of the geopolitical setting and its significance. 
International Journal of Arts and Humanities

ISSN: 2581-3102

Volume: 04, Issue: 03 "March 2020"

The Red Sea coast line 2,234 km Red Sea Coastline of the State of Eritrea and the coastal lines of Egypt starting from the mouth of the Suez canal through Sudan and Djibouti covers more than $4000 \mathrm{~km}$. The Somali coast line of the Indian ocean is $3025 \mathrm{~km}$ long having multiple ports of vital regional and international importance. The ports along the Red Sea and Indian Ocean are strategic spots that continued to be points of attraction to regional and international actors; these include port Sudan, Massawa and Assab in Eritrea, Djibouti port, Bossaso in Punt land, Berbera and Mogadishu in Somalia, Mombassa in Kenya, on the other side of the Red sea and Gulf of Aden Jeddah in Saudi Arabia and Aden and Ash Shihir in Yemen (Congressional Research Service, 2009). The Horn Coastline of the Red Sea joining the Mediterranean world via the Suez canal to South through the strait of Bab el Mandeb to Gulf of Aden to the Arabian Sea and the wide world of Indian Ocean on the one hand; the shipping line from Persian Gulf via Gulf of Oman crossing the Arabian sea to the Indian ocean on the other meeting at Mombasa (Kenya) parallel leading to the Cape of Good Hope and the Atlantic ocean is key strategic shipment line that joins Africa, the Middle East, the Indian Sub-continent and Europe. State of affairs on this part of the world constitutes global concern (ibid). For long control over this international shipment line has determined the power of regional and international actors in turn determining the state of war and peace, conflict and cooperation, peace and security in the Horn regional setup.

The post September 11 period has refreshed and reinvigorated the interest of big powers with composition of emergent factors; at the fore front are radical Islam, terrorism and the coming of China to Africa. This has dual expressions rooted in the effect of globalization that made events in any part of the world to be concern for all; more so does in terms of any form of security; one is the growing concern and eventual declaration of Global War on Terror. The level of concern is seen in the US sharing the French base in Djibouti, the formation of East African standby brigade and aids to Djibouti and Ethiopia as part of alliance of the willing in the fight against terrorism. ${ }^{1}$ (Combined Joint Force, 2008). The second is economic concern to curb the influence of China; last but not least, the rise of piracy on the Indian ocean coastal lines of Somalia has become combining factor not only for states of the Horn but also for rival big powers, to which both the US and China take measures unilaterally in different time frames. Owing to this geopolitical significance of the region and the newly invigorated China's engagement with African states in general and the Horn of African states in particular, China is playing a central role in the promotion of security in the coastal areas of the region as well as in the peacemaking efforts of the most troubled states of the region. It is in lieu of this imperatives and sine qua non,

${ }^{1}$ Combined Joint Force (2008) Bulletin, 3. Combined Joint Force is part of US 'war-on terror' in-Horn of Africa comprises Ethiopia, Djibouti, Kenya and Yemen as its members, and has been expanding its coverage since 2002 to encompass Eritrea; conducts operations and training within the Combined Joint Operations Area (CJOA) to assist Host Nations to combat terrorism in order to establish a secure environment and enable regional stability. 
International Journal of Arts and Humanities

ISSN: 2581-3102

Volume: 04, Issue: 03 "March 2020"

that China's engagement in the region should be seen. This is elaborated in details following the theoretical aspect of the discussion.

\section{THEORETICAL BASELINE}

\subsection{Great Powers Responsibility in the Maintenance of Peace and Security}

Power is central concept in the realist tradition of International Relations. Power often defined in terms of material capability is identified as the ultimate enabling mechanism or instrument of a state to secure its national interest, at the core of which is survival. From this realist understanding of power, we can deduce that great power entails the military capability of a state relative to the military capability of others. According to Mearsheimer (2001) a given state can be named as a great power when it achieves a stage capable of waging conventional war, not necessarily win, against an existing power preponderant. Great powers, while fear each other, continually compete for power with the ultimate objective of becoming a hegemon (ibid). So from realist point of view, great power responsibility emanates from this fact of military strength.

Another explanation is given from the English School. This School of International Relations, define great power status and Great power responsibility in terms of both material capability and its intersubjective social role. In essence, it claims that not only military power that defines great power and its concomitant responsibility. Hence, the School "engineers an important shift from realism by introducing a social element into conceptualisations of great power responsibility" by complementing the concept of social role (Lock, 2015). Conceptualization of great power and its status is attributed to its power and contribution in the maintenance of international peace and order as deemed legitimate and accepted by other members of the international community (Bull, 1977, cited in Lock, 2015).

The concept of responsibility is a social constructionist idea attached with the moral and legal obligation of an entity, in our case the state. For instance, owing to their power, big powers have secured veto status in the Security Council and hence have the legal responsibility to act rationally in the maintenance of international peace and security. Besides, big powers have irreplaceable role in determining the nature of the international system. And hence, they have the moral responsibility to help address social evils across the globe.

In the context of prevalent international law and international relations, states are presumed equal yet they are different in terms of the distribution of capabilities like military, economic wellbeing, technological knowhow and international reputation. With such taken for granted differences, great powers have a special responsibility to mediate the idea of sovereign equality and the unequal distribution of capabilities (Bukovansky, 2012). Great powers are responsible for determining issues that affect the peace and security of the international system as a 
International Journal of Arts and Humanities

ISSN: 2581-3102

Volume: 04, Issue: 03 "March 2020"

whole, and have a duty to shape and adjust their foreign policies with those desirable international conditions. Thus, they can't escape the critics for failing to respond accordingly (Jackson, 2003, as cited in Kenkel, 2016).

In general, in contemporary International politics and Relations, the major powers are assumed to play their part in redressing the social and political evils engulfing countries of the poor. This might encompass many aspects, among others, supporting peace initiatives and helping promote security endeavors of poor states are few to mention. It is also imperative to take into account that States engagement in the peace making effort is not solely driven from their global responsibility. Notwithstanding their big power responsibility, they have the obvious reason for active involvement in the peace making and security promotion endeavors in general. This is typically defined as states national interest. This interest is at the core of their foreign policy objectives, for its attainment they pursue all instruments, called instruments of foreign policy that includes from peaceful to violent mechanisms.

In terms of their approach, either unilateral or multilateral, or a mix of both ways is possible in so far as it confirms the basic underlying assumptions of International law and International Organizations. Here contextual matters might have ample explanatory power in the choice of approaches, for instance big powers might think that their unilateral action is more doable to address a certain challenge, or a multilateral approach via international, regional and subregional organizations. In some cases, some contexts might demand a mix of both approaches and under such instance big powers might convince themselves to involve and contribute their fair share via both mechanisms in different capacity. It is in lieu of this theoretical underpinning that Chinese engagement in the promotion of peace and security in the region of the Horn of Africa will be meticulously discussed.

\subsection{Conflict and Conflict Resolution and Transformation}

Scholars of conflict studies define the essence of conflict in various ways. For instance, Musalaha (2017:3)defined conflict as "an expressed struggle between at least two interdependent parties who perceive incompatible goals, scarce resources, and interference from others in achieving their goals."Jeong (2008:18) also defined it as "persistent and pervasive nature of inter-group and international competition among disparate interests and values that underlies power dynamics". Others also defined it as a struggle or contest between people/ groups or states with contradictory needs, ideas, beliefs, values, or goals (Azar, 1986; Burton, 1990). Deducing from the definitions above, the phrase "disagreement over something" is elemental factor in understanding the concept conflict. Besides, most conflict scholars believe that conflict among individuals or actors is natural phenomenon in any society, yet what matters most is how we handle them before going violent. Because, conflict in its violent form claims the lives of 
International Journal of Arts and Humanities

ISSN: 2581-3102

Volume: 04, Issue: 03 "March 2020"

many people, destroys economic resources, infrastructures and diverts resources like human and financial away from the development needs of the public (Azar, 1986).

In view of this, instruments or efforts to handle conflict is vital. Among others conflict prevention is one of the mechanisms via which we can handle conflicts before going unabated. Conflict prevention entails a constant monitoring of potential flashpoints and a very immediate action to remove the conditions that might facilitate to the outbreak of a violent conflict. Here its minimalist objective is to block a certain crisis from spilling into an open violent conflict (Jeong, 2008). In case this approach fails, the situation calls for conflict management and resolution mechanisms. The first is aimed at containing the damages and limiting the scale of the conflict, while the second is aimed at helping parties to the conflict address conflicts altogether in a winwin situation. Conflict resolution processes might include a number of approaches like negotiation, mediation and arbitration. For a successful Conflict resolution, efforts need to extend beyond resolution to include peace efforts like post conflict peace building and reconstruction.

Another modality of addressing conflicts is conflict transformation. As a theory, conflict transformation is aimed at ending the very underlining causes of conflicts and arriving at a sustainable peace. Thus, it seeks to go beyond conflict management and resolution efforts and aspires the development of a healthy relationships among communities or states. As a theory or an approach, conflict transformation recognizes any sort of social conflict as a continuous and dynamic behaviour in human relationship. And hence, it is much more concerned with social conflicts. According to Lederach (2003) the theory of conflict transformation underscores that social conflict is evolving from and producing change in the personal, relational, structural and cultural dimensions of human experience.

\section{CHINA'S ENGAGEMENT IN THE PROMOTION OF PEACE AND SECURITY IN THE REGION}

The history of China's engagement with the African continent can be traced back to the $15^{\text {th }} \mathrm{C}$ during which Chinese traders visited East African region. In its modern parlance, however, China-African relation was built around 1950's (Schiere, 2011). This was the period that involve two imperatives in building the foundations of China-African relations. One is that significant number of African states were under colonial rule, hence most of them demand external support in their fight against colonialism and postcolonial politico-economic reconstruction. The second is that following the formal establishment of the Chinese People's Republic in 1949, China was in need of international political support and recognition for its one China policy, and concomitant support to join the UN. This mutually demanded cooperative trend was officially invigorated with the declaration of the Bandung summit of 1955, in which about 29 high level 
International Journal of Arts and Humanities

ISSN: 2581-3102

Volume: 04, Issue: 03 "March 2020"

politicians from across Africa and Asia were participants ${ }^{2}$. During the summit, they agreed up on five principles ${ }^{3}$ to be instrumental in their aspiration for South-South cooperation. This has laid the bases for the China-Africa relations. This general image in the making of China- Africa relations has its importance in the explanation of Chinese engagement in the Horn of Africa. Given this, as it may, the current Chinese engagement in the region might need further explanations related to geopolitics, economic, political and security matters.

The geopolitical position of the Horn of Africa region and associated politico-economic and security interest of China is one explanation in this regard. While highlighting the geopolitical significance of the region, Buys (2017:10) states that "East Africa's coastal countries are important not just in their own right, but also through their role as transport nodes linking Indian Ocean trade routes with the African interior". Following the formation of the Forum on ChinaAfrica (in 2000), China has significantly involved in economic relations, manifested in trade and investment, with almost all East African countries. Since the first Forum on China-Africa, observers believe that "the United States has shared the region with China, splitting interests between America's military-industrial security sphere and China's economic and trade relations" (IARAN, 2017). Besides, the "Maritime Silk Road" initiative planned to connect China, Europe and Africa is a must to stretch via the Horn region so as to reach the regions and states of the African continent. This is another geopolitical explanation in the relations of China with the Horn of Africa. In this regard, countries like Djibouti, Sudan, Ethiopia and Kenya are of particular strategic significance to the Maritime Silk Road (Breuer, 2017). Chinese demand for natural resources and market in the East African Region are another explanation for the Chinese engagement in the region. On the part of the states in the Horn region, they have relatively easy access to the financial support, basically in the form of grants and concessional loans from the Chinese government. This creates a leeway for the states of the Horn of Africa from the complex political economic prerequisite of western countries and their financial institutions. All stated points, at least indicate the mutual interest of China and the states of the Horn of Africa region for mutual benefit. To assure this, thus, China's contribution in the maintenance of peace, stability and promotion of security in the region has become a vital issue of concern. Within this general conception, Chinese engagement in the promotion of peace and security in the Horn of Africa region can be seen in the following manner.

A. China's Military Base in Djibouti and its Fight against Pirates in the region: Since the fall of the authoritarian military regime, Somalia has become an anarchic state where clan

\footnotetext{
${ }^{2}$ Bandung summit held in Indonesia from April 18-24, 1955. This was known to be one of the first important conferences in the initiation and promotion of a new south-south cooperation.

${ }^{3}$ The principles are outlined in the final communique of the summit. These are, political self -determination, mutual respect for sovereignty, Equality, non-aggression and non-interference in the internal affairs of another.
} 
International Journal of Arts and Humanities

ISSN: 2581-3102

Volume: 04, Issue: 03 "March 2020"

leaders fought each other for power and resource control. The absence of central government in Somalia has created a safe zone for groups engaged in banditry, terrorism, human trafficking, transfer of small arms and light weapons, black marketing etc. Besides, pirates were operating in the coastal areas of Somalia all along the Gulf of Aden that affect the longest trade route of the Red Sea, connecting the Mediterranean Sea to the Indian Ocean. Several times failed naval missions were conducted by the fragile Somalian Government in collaboration with neighboring states. This had amplified supporting hands from the international community. Since 2008, when the security situation has become worsened, China has conducted 26 escorts mission not only to Chinese but also non-Chinese commercial ships in the coastal areas of Somalia and the Gulf of Aden (CGTN, August, 2017). Furthermore, in 2017, for the first time, China sent a special force of navy's groups called Dragon Commando so as to rescue a merchant ship in the Gulf of Aden that resulted the capture of three pirates and able to free16 Filipino crew members(Jun,2018). Since then, China has showed great interest in the fight against pirates in the region.

Side by side, owing to the strategic significance of the region, various powers, like France, Britain, USA and Japan have established their overseas military base in Djibouti. Djibouti, located in the eastern most tip of the Horn region, is also a linchpin to the Chinese one belt one road initiative, it is via which to intrude the African continent. Hence, China has established its first overseas military base in Djibouti in $1^{\text {st }}$ August 2017 with a total cost of 590 million US Dollars. The military base is operated by Chinese People's Liberation Army Navy/中国人民解放军驻吉布提保障基地. According to the CGTN (CGTN, August 2017), the military base of China will help it to fulfill china's international obligation like peacekeeping mission and humanitarian aid operations in the region. Currently, China is actively superintending the area from pirates. Parallel to the establishment of the military base, China has built a port and a free trade zone in Djibouti, which makes it totally different from previously established powers in the country. Hence, it is lucid to depict that China has made Djibouti as its safe gateway to the African continent. With such interest in Djibouti and similar politicoeconomic interest in the region, it seems laudable that China will significantly contribute to the peace and security need of the Horn of Africa region.

B. China's Participation in Peacekeeping Mission: for a very long time, China preferred to engage in matters of peace and security individually than via multilateral arrangements. However, since the last ten years, it has accepted to participate in peacekeeping efforts under the umbrella of the United Nations. Currently, China is one of the top contributor of military personnel among the five permanent members of the UN. Viewed from this angel, Chinese contribution to the promotion of peace and security in the Horn of Africa is praiseworthy. In addition to its state to state approach, it's playing significant role in terms of both financing peace operations and sending military personnel. For instance, in 2009 China has donated about 
International Journal of Arts and Humanities

ISSN: 2581-3102

Volume: 04, Issue: 03 "March 2020"

300,000 US Dollars to the African Mission in Somalia (AMISOM), in 2010 China financed about 1.32 million to the African Union (AU), out of which some portions are allocated to the mission in Somalia, and in 2016 it has donated 1.8million Dollars to the African Union mission in Sudan (Safeworld, 2011). In terms of human resources contribution, China has contributed about 231 troops to the AU-UN mission in Darfur. Similarly, it has contributed 1042 troops and 15 civilian police to the United Nations Mission in South Sudan (Etyang, August 2016).

\section{Post conflict reconstruction and peace building in Somalia}

Besides, to the struggle against pirates in the horn region and its contribution in the peacemaking efforts in Sudan, China is playing a significant role in the post conflict peace building and reconstruction of Somalia. Currently, notwithstanding all odds, Somalia seems in a relative peace, yet its central government is weak to address the security and economic needs of the people. Especially, as a war torn country, massively devastated by civil war, Somalia demands organizational or state level support in its post conflict peace building and reconstruction aspiration. In this regard, among others, China is playing this part. For instance, sources indicate that China has built more than 80ninrastractural projects like roads, stadium, hospitals, and schools in the last 30 years (CGTN, $31^{\text {st }}$ August 2018). In the same period, since 1991, to date, it has dispatched a group of medical experts having more than 400 members within 13 batches, indicating Chinese huge engagement in the reconstruction process. Besides, China has provided about 1.5 million US dollars for humanitarian purposes in May 2018. On the other hand, since 2018, Somalia officially joined the Chinese One belt one road initiative. And recently Somalia has issued fishing license for about 30 Chinese companies to operate in its coastline. These will surely reinvigorated Chinese contribution in the promotion of peace and security in the region, not only from the vintage point of big power responsibility but also from its own angle of promoting its national interest.

\section{Mediating the Peace Process in South Sudan and Sudan}

Chinais engaged in South Sudanese peace talks, in which both parties of the conflict has welcomed its effort (Xinhua, 27 ${ }^{\text {th }}$ May, 2018).Previous mediating efforts by other third parties were unsuccessful mainly due to lack of mutual acceptance and suspicion to the partiality or impartiality of the actors involved in the mediating process. But unlike others, Chinese mediating effort is recognized as impartial by all sides of the conflict, which is a good move towards a peaceful solution in South Sudan. Besides, similar undertakings are undergoing in the conflict between south Sudan and the Republic of Sudan. Like the case in the peace talks in South Sudanese civil war, Chinese mediating role is also accepted by both parties in the interstate conflict of South Sudan and the Sudan. Hence, Currently, Chinese Mediating effort in the civil war of South Sudan and the Border conflict of North-South Sudan seems plausible. 
International Journal of Arts and Humanities

ISSN: 2581-3102

Volume: 04, Issue: 03 "March 2020"

\section{CONCLUSION}

The Horn of Africa encompassing eight sovereign states has a unique political feature that more or less determine the nature of regional peace and security agenda. Authoritarian modus operandi and state centered security conception are built-in features of the regional politics. Owing to this and associated factors, mutual intervention in the internal affairs of one another and the concomitant effect of regionalized civil wars, mutual suspicion and interstate conflicts are defining characteristics of interstate relations in the region. Besides, the popular saying 'enemy of my enemy is my friend' and concomitant effects of it on interstate relations flawlessly works in the region.

The geopolitical significance of the region has also its own impact in determining the peace and security agenda of the region, as it attract major powers to the region and the regional issue. For good or bad, the geopolitical significance of the region has witnessed a swapped weight across time and history. It has a marked significance in the high days of colonialism and the Cold War period. However, declined with demise of the Soviet Union and American power preponderance in the immediate days of post-Cold War politics. Yet, very recently, the geopolitical significance of the region has come to a point of its pick where great powers are increasing their petition for the region. This can be seen in terms of US interest in the fight against terrorism and political Islam and the reinvigorated economic engagement of China in Africa, and its quest for the one belt one road initiative. On the other hand, the regional absence of peace and incredible instability and insecurity has attracted global powers to play their role in ameliorating the debacle. The heightened frequency of pirate attacks, terrorist assaults, interstate and intrastate conflicts (like in Somalia and Sudan) and their concomitant effect has come to be on the agenda of the great powers, without which they can't realize their aspiration, what so ever it constitutes, in the region and Africa in general. Thus, responsible global powers are contributing their fair share in this regard. Here, China is a case in point that has long involved in fighting against piracy in the coastal areas of Somalia, Red sea and the Gulf of Aden. Besides, it is actively engaged in the peacekeeping efforts of the UN in South Sudan, in conflict resolution and mediation process in Sudan and South Sudan. Besides to its contribution in different capacity to the post conflict peace building in Somalia, it is also participating in helping the peace efforts of regional (African Union) and sub-regional (IGAD) frameworks. Yet its contribution is limited only to intergovernmental organizations and government institution, hence massively criticized from the advocates of peace via civil society organizations and human right activists. 
International Journal of Arts and Humanities

ISSN: 2581-3102

Volume: 04, Issue: 03 "March 2020"

\section{REFERENCES}

Azar, E. (1986) 'protracted international conflicts: ten propositions', in E. Azar and J. Burton (eds), International Conflict Resolution: Theory and Practice. Boulder, CO: Lynne Rienner

Bereket Habtewold (1980) Conflict and Intervention in the Horn of Africa (New York: Monthly Review Press

BJØRN MØLLER (2007) The Horn of Africa and the US "War on Terror" with a Special Focus on Somalia. Aalborg University, 5 October, 2007.

Burton, J. W. (1990) Conflict Resolution and Prevention. New York: St. Martin's Press

CGTN China pledges to support Somalia's development, 2018-08-31 13:50 GMT+8 accessed at https://news.cgtn.com/news/3d3d514d3363444f79457a63335666d54/share p.html

CGTN, 2017-08-02 14:21 CGTN Editor: Liang Meichen. China's first overseas military base opens in Djibouti, accessed at "http://www.ecns.cn/m/video/2017/08-02/267774.shtml"

Congressional Research Service. April 24, 2009. Piracy off the Horn of Africa.

Danfulani, S (1999) Regional security and conflict resolution in the Horn of Africa: Somalian reconstruction after the Cold War, International Studies.

Etyang, Oita (2016), China and Africa's Peace and Security Agenda: The Burgeoning Appetite. Journal of African conflicts and Peace studies, August Vol 1, Issue 1

Farer, T (1979) War clouds on the Horn of Africa: the widening storm, New York: Carnegie Endowment for International Peace

Jeong, Ho-Won (2008) Understanding Conflict and Conflict Analysis. SAGE Publications, London.

Juma, Monica Kathina (2003) "The Intergovernmental Authority on Development and the East African Community," in Mwesiga Baregu\& Christopher Landsberg (eds.): From Cape to Congo. Southern Africa's Evolving Security Challenges

Jun Mai (February 18, 2018), South China Morning Post; 'China's Somali pirate-catching commando gets a hero's welcome, accessed at https://www.scmp.com/news/china/society/article/2133731/chinas-somali-piratecatching-commando-gets-heros-welcome-back 
International Journal of Arts and Humanities

ISSN: 2581-3102

Volume: 04, Issue: 03 "March 2020"

Lederach, John Paul (2003). Little Book of Conflict Transformation: Clear Articulation Of The Guiding Principles By A Pioneer In The Field

Lyons, Terrence B (1992) "The Horn of Africa Regional Politics: A Hobbesian World," in Howard Wriggins (ed.): Dynamics of Regional Politics. Four Systems on the Indian Ocean Rim (New York: Columbia University Press

Mearsheimer, J. J. (2001). Anarchy and the struggle for power. In: The tragedy of great power politics. New York and London: W W Norton \& Company

Mu'uzGidey, (2010) The Geopolitics and Human Security.

Musalaha (February 10, 2017) Conflict Management, Conflict Resolution, Conflict Transformation. Accessed at http://www.musalaha.org/articles/2017/2/10/conflictmanagement-conflict-resolution-conflict-transformation-1

Robert I. Rotberg (2005) 'the Horn of Africa and Yemen: Diminishing the Threat of Terrorism' in Robert I. Rotberg (ed.). Battling Terrorism in the Horn of Africa. World Peace Foundation Cambridge, Massachusetts. Brookings Institution Press Washington, D.C.

Safeworld, 2011 China's Growing Role in African Peace and Security. Accessed at "https://www.saferworld.org.uk/downloadfile.php?.../Chinas\%20Growing\%20Role\%20in $\ldots ”$

Woodward, Peter 2002. The Horn of Africa: State, Politics and International Relations. I.B. Tauris \& Co. Ltd, Salem Road, London.

Xinhua news, 2018-05-27 19:21:44South Sudan welcomes China's peace mediator role: ambassador accessed at "http://www.xinhuanet.com/English/201805/27/c_137210256.htm". 